\title{
Picogram per Minute
}

National Cancer Institute

\section{Source}

National Cancer Institute. Picogram per Minute. NCI Thesaurus. Code C85782.

Picograms per minute. 